\title{
Kesadaran Identitas Diri dalam Komunikasi Lintas Budaya pada Pembelajaran Percakapan Bahasa Jepang Tingkat Dasar: Identitas Muslim dan Orang Indonesia
}

\author{
Vera Yulianti ${ }^{1}$, Arianty Visiaty ${ }^{2}$ \\ ${ }^{1}$ Program Studi Sastra Jepang, Fakultas Sastra, Universitas Al Azhar Indonesia, Jl. Sisingamangaraja, \\ Kompleks Masjid Agung Al Azhar, Kebayoran Baru, Jakarta 12110 \\ Penulis untuk Korespondensi/E-mail: vera.yulianti@uai.ac.id
}

Abstrak - Penelitian ini bertujuan mengidentifikasi kesadaran diri pembelajar bahasa Jepang mengenai identitas budaya muslim orang Indonesia pada pembelajaran bahasa Jepang tingkat dasar dan perbandingannya dengan identitas diri budaya Jepang. Responden penelitian ini adalah dua puluh satu mahasiswa tingkat 1 Universitas Al Azhar Indonesia yang sedang mengikuti kuliah percakapan bahasa Jepang 2. Seluruh responden adalah pembelajar bahasa Jepang tingkat dasar kategori A1 menurut CEFR dan 2010. Dengan menggunakan portofolio dan rubrik, pembelajar mengeksplorasi identitas dirinya sebagai muslim dan orang Indonesia berkaitan dengan tema percakapan yang ditentukan, kemudian membandingkannya dengan identitas budaya orang Jepang dengan stimulant video dan ilustrasi. Lalu, responden bercakap dengan bermain peran (role play) tema terkait, kemudian mengevaluasi kendala yang muncul. Hasil penelitian ini mengungkapkan bahwa identitas budaya sebagai muslim orang Indonesia yang disadari responden pada komunikasi interkultural banyak dipengaruhi oleh konsep bangsa yang beranekaragam namun satu kesatuan (Bhinneka Tunggal Ika). Keberagaman tersebut memunculkan kecenderungan orang Indonesia cenderung mudah terbuka pada orang lain, sekalipun saat bercakap-cakap dengan orang yang baru dikenal dan membicarakan topiktopik yang sifatnya pribadi sekalipun seperti indentitas pribadi dan keluarga. Lalu, identitas sebagai seorang muslim banyak muncul dalam percakapan komunikasi interkultural terutama mengenai aturan praktek ibadah sehari-hari. Penjelasan tentang praktek ibadah yang khas ini cenderung memunculkan kesulitan percakapan (pemilihan kosakata dan ungkapan) dalam bahasa Jepang bagi pembelajar tingkat dasar. Sementara identitas budaya masyarakat berkelompok (collectivistic culture) banyak mewarnai percakapan orang Jepang dalam komunikasi interkultural sehingga mereka cenderung lebih menjaga privasi diri dan kelompok.

Kata Kunci - Pembelajar bahasa Jepang, Identitas budaya, Komunikasi lintas budaya

Abstract - Despite intercultural communication competence as one of the important language learning process goals since globalization has started, there comes a tendency to neglect to foster cultural identity awareness in language learning process. This research is a preliminary study that explores Indonesian learner's cultural identities awareness as well Japanese cultural identities during the process of learning the Japanese language as one of their foreign languages. The respondents are twenty-one students of Japanese language classes participating in Japanese language speaking class 1 (elementary level) at Al Azhar Indonesia University, categorized as A1 (beginner) Japanese learners by JF (Japan Foundation) standards. Through two conversation topics ("my family" and "my home town") the respondents have been invited to mention their local custom while conversing within the topics and comparing such custom to Japanese people's local custom. The data are collected utilizing portfolios and Likert scale prepost questionnaire during November 2016 and analyzed descriptively. The result of this study exposed that the participants were aware of Indonesian cultural identity and Japanese cultural identity in the context of intercultural communication, namely, in the conversation of family and hometown. While having a dialogue with unfamiliar people, mainly speaking about 
personal information, i.e. family topic, Japanese people tend to have conversation plainly in general subtopics since Japanese people have collectivistic culture. Distinctively, since Indonesian people believe in "Unity in Diversity" (different but one), they are feasible to discuss wider subtopics despite the unfamiliar interlocutors.

\author{
Keywords - Indonesian, Japanese Language Learners, Cultural Identity, Intercultural \\ Communicative Competence
}

\section{PENDAHULUAN}

\section{Latar Belakang}

$\mathrm{D}$ alam proses pembelajaran bahasa asing, pemahaman akan budaya bahasa target (L2) adalah hal yang tidak dapat dipisahkan. Proses pemahaman akan latar belakang budaya L2 akan menjadi penentu untuk menguasai Bahasa L2. Namun, dalam konteks komunikasi lintas budaya (intercultural communication), kesadaran penutur akan identitas diri masingmasing juga memainkan peranan penting.

Berkaitan dengan pemahaman di atas, dalam proses pembelajaran bahasa asing terdapat fenomena masalah mengenai krisis identitas diri pada pemelajar bahasa asing. Tidak sedikit pembelajar bahasa asing yang dapat memahami budaya bahasa L2 yang dipelajarinya, bahkan meleburkan dirinya ke dalam budaya tersebut. Pembelajar-pembelajar ini beranggapan bahwa tujuan mempelajari bahasa dan budaya asing adalah untuk menjadikan dirinya seperti penutur asli bahasa L2 termasuk budaya yang melekat pada bahasa L2. Seiring dengan waktu dalam proses pembelajaran bahasa L2 tersebut, mereka mulai mengalami krisis identitas diri yang dibawanya sejak lahir. Muncul fenomena pemelajar tidak tahu bagaimana harus mengekspresikan identitas dirinya atau sebaliknya memahami identitas orang lain saat berkomunikasi dalam bahasa L2. Fred E Jandt (2012) [1] mengungkapkan beberapa faktor hambatan-hambatan dalam komunikasi lintas budaya di antaranya adalah rasa canggung, perasaan merasa berbeda atau sebaliknya menyamaratakan tentang budaya dirinya atau budaya mitra komunikasinya termasuk mengenai identitas diri.

Dengan adanya fenomena masalah identitas diri dalam proses pembelajaran bahasa asing seperti yang diuraikan di atas, Byram (2002) [2] mengajukan beberapa pengetahuan, keahlian, sikap dan nilai yang harus ditanamkan dalam proses pembelajaran bahasa asing agar pemelajar tidak hanya menguasai kompetensi linguistik belaka, namum juga kompetensi komunikasi lintas budaya (intercultural communicative competence). Dengan penguasaan ini maka pemelajar bahasa asing tidak akan canggung untuk mengungkapkan identitas dirinya, maupun dapat terbuka memahami identitas orang lain. Lebih lanjut Byram menjelaskan bahwa salah satu nilai penting yang harus ditanamkan adalah "critical cultural awareness" yaitu kemampuan untuk memahami budaya orang lain bersamaan dengan kemampuan mengekspresikan identitas budayanya sendiri ( hal.11-13 ).

Fenomena krisis identitas diri ini juga dijumpai pada pembelajar bahasa Jepang di Indonesia. Berdasarkan pengalaman peneliti sebagai pemelajar dan pengajar bahasa Jepang selama bertahun-tahun, tidak sedikit orang Indonesia pembelajar bahasa Jepang yang beranggapan target akhir dari proses pembelajarannya adalah menjadikan dirinya seperti orang Jepang. Muncul perasaan malu, canggung, sungkan dan tidak tahu bagaimana mengekspresikan identitas dirinya sebagai orang Indonesia umumnya dan khususnya sebagai muslim yang sebenarnya merupakan identitas diri yang utama yang mempengaruhi kehidupan sehariharinya di manapun ia berada. Misalnya, mereka canggung dan bingung ketika harus menjelaskan etika pergaulan orang Indonesia dan makanan halal di hadapan penutur bahasa Jepang. Tidak sedikit yang memilih "terpaksa" mengikuti budaya Jepang meski sebenarnya orang Jepang dalam ketidakpahamannya akan budaya dan identitas orang Indonesia dan muslim, tidak pernah memaksa mitra komunikasinya mengikuti budaya mereka.

Oleh karena itu, penelitian mengenai identitas diri dalam konteks komunikasi lintas budaya pada pembelajaran percakapan bahasa Jepang menjadi penting. Dengan penelitian ini, tidak hanya kompetensi linguistik saja yang ditanamkan pada pemelajar bahasa asing, 
namun juga kompetensi komunikasi lintas budaya sehingga ia dapat memahami identitas orang lain, namun juga tidak canggung dalam mengungkapkan identitas dirinya ketika berkomunisi dalam bahasa asing.

\section{Perumusan Masalah}

Masalah yang akan dijawab dalam penelitian ini akan diuraikan dalam pertanyaanpertanyaan berikut:

> Seperti apa pembelajar menyadari indetitas budaya dirinya sebagai orang Indonesia dan muslim dan bagaimana identitas budaya orang Jepang sebagai mitra komunikasinya?

> Pada percakapan Bahasa Jepang tingkat dasar, tema atau situasi percakapan seperti apa yang memungkinkan pembelajar mengekspresikan identitas dirinya sebagai seorang muslim dan orang Indonesia?

$>$ Kendala-kendala apa yang dihadapi pemelajar saat mengekspresikan identitas dirinya sebagai muslim orang Indonesia saat berkomunikasi dalam bahasa Jepang?

\section{Tujuan}

Penelitian ini bertujuan mengidentifikasi kesadaran pembelajar bahasa Jepang tingkat dasar mengenai identitas dirinya sebagai orang muslim dan orang Indonesia serta indentitas budaya orang Jepang dalam konteks komunikasi interkultural pada pembelajaran percakapan bahasa Jepang tingkat dasar. Selain itu, penelitian ini juga bertujuan mengidentifikasi fungsi dan tema percakapan yang dapat mengembangkan potensi kompetensi komunikasi interkultural tingkat dasar serta kendala-kendala yang dihadapi pemelajar bahasa Jepang orang Indonesia saat mengungkapkan identitas dirinya sebagai muslim orang Indonesia dalam berbagai tema tersebut.

\section{Manfaat Penelitian}

Manfaat penelitian ini mencakup aspek kompetensi komunikasi lintas budaya dalam pemerolehan bahasa asing sebagai bahasa kedua (Second Language Acquisition). Manfaat tersebut akan diuraikan sebagai berikut.

Pertama, pengajar mendapat masukan mengenai tahapan dan hal-hal yang harus diperhatikan saat mewacanakan kesadaran identitas diri dalam perencanaan satuan pengajaran bahasa Jepang dimulai dari kelas di tingkat dasar. Kesadaran identitas diri yang dimaksud terkait dengan budaya dan agama.

Kedua, melalui penelitian ini diharapkan kesadaran akan keanekaragaman identitas muslim orang Indonesia dapat dipahami dan diterima dengan baik oleh penutur orang Jepang, demikian pula juga sebaliknya sehingga pemahaman identitas kedua belah pihak menjadi lebih baik.

\section{Ruang Lingkup Penelitian}

Penelitian ini akan mengacu pada teori yang dikemukakan Byram (2002) mengenai pengembangan dimensi lintas budaya dalam pengajaran bahasa, Fred E. Jandt (2012) yang mengkaji tentang identitas dalam komunikasi lintas budaya pada komunitas global, serta Anthony J. Liddicoat (2013) mengenai pembelajaran bahasa dalam lintas budaya. Selain itu, hasil penelitian Andisheh Saniei (2012) mengenai pengembangan kesadaran budaya dalam bahasa ajar pembelajaran bahasa juga akan menjadi salah satu referensi utama untuk melaksanakan penelitian ini.

Metode penelitian yang akan dilakukan adalah penelitian tindakan kelas (Action Research) dengan responden peserta kuliah percakapan bahasa Jepang 2 (Kaiwa 2) di Universitas Al Azhar Indonesia sebanyak 21 orang. Sumber data tema percakapan akan diambil dari buku ajar utama Minna no Nihongo 1 untuk pendekatan fungsi bahasa dan buku ajar Marugoto A0-A2 untuk pendekatan tema budaya.

\section{LANDASAN TEORI}

\section{Identitas Diri dalam Komunikasi Lintas Budaya}

Stuart Hall [1] mendefinisikan 'identitas diri' dalam dua definisi. Kedua definisi tersebut adalah "persamaan dalam sekelompok orang" dan "persamaan dan perbedaan antara kelompok di dalam masyarakat".

Kemudian Fred E. Jandt [2] menyatakan bahwa identitas diri seseorang tidak bisa berlepas dari identitas budaya kelompok di mana orang tersebut bernaung sebagai bagian dari anggota kelompok tersebut. Kekuatan yang akan menentukan keberhasilan dan komunikasi 
lintas budaya adalah 'konsep diri', ' pencarian diri', 'monitor diri' dan ' relaksasi sosial ' .

Lebih lanjut, Fred E.Jandt menejelaskan [3] 'konsep diri' yang dimaksud adalah konsep bagaimana ia memandang dirinya sendiri dalam lingkup sosial. Sedangkan 'pencarian diri' adalah sebuah keinginan untuk terbuka mencari informasi tentang dirinya dalam pandangan kelompok di mana ia berinteraksi. Adapun 'monitor diri 'yang dimaksud adalah upaya untuk memantau keberadaaan dirinya di tengah kelompok sosial tempat ia berinteraksi. Sedangkan 'relaksasi sosial' yang maksud adalah sikap lentur dalam berinteraksi ketika kecemasan muncul saat berkomunikasi. Dengan penjelasan di atas, dapat dikatakan bahwa penutur yang memahami dengan baik konteks komunikasi lintas budaya harus mempunyai kesadaran diri yang tingi yaitu dapat memahami identitas dirinya dengan baik sebagaimana ia memahami identitas diri mitra komunikasinya, serta bersikap positif dan lentur ketika terjadi perbedaan dalam berkomunikasi.

\section{Kompetensi Penutur Komunikasi Lintas Budaya dalam Pengajaran Bahasa Asing}

Byram [4]-[6] menjelaskan bahwa untuk menjadi penutur dalam komunikasi lintasi budaya terdapat empat komponen kompetensi komunikasi lintas budaya yang harus dikuasai melalui proses pembelajaran bahasa. Empat kompenen kompetensi komunikasi lintas budaya tersebut adalah 'pengetahuan' (knowledge), 'keahlian' (skills), 'sikap' (attitude) dan 'nilai identitas diri' (individual identity values). Model komponen kompentesi komunikasi interkultura yang dikemukakan Byram ini terlihat pada gambar 1.

'Pengetahuan' (knowledge) yang harus dikuasai dalam komponen kompetensi lintas budaya adalah pengetahuan mengenai kelompokkelompok sosial, proses interaksi dalam kelompok sosial tersebut dan luaran dari proses interaksi kelompok-kelompok sosial tersebut. Pengetahuan tersebut juga termasuk pengetahuan bagaiamana kelompok sosial tersebut memandang dan menerima keberadaan penutur itu sendiri.

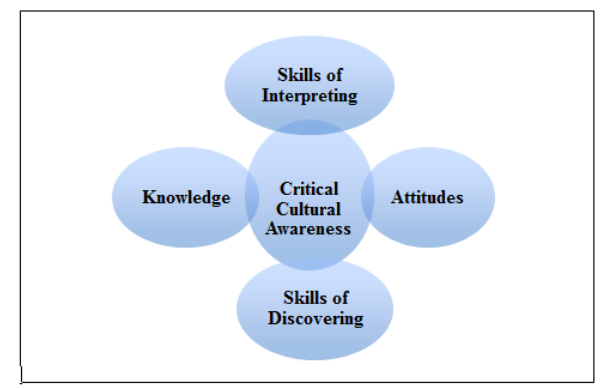

Gambar 1. Model Byram’s (1997) “Kompetensi Komunikasi Interkultural"

Kemudian, 'kemampuan' (skills) yang selayaknya dikuasai penutur komunikasi lintas budaya adalah kemampuan menafsirkan, membandingkan, menemukan dan berinteraksi dengan kelompok masyarakat dari budaya yang berbeda. Dengan menguasai berbagai kemampuan tersebut diharapkan penutur akan memahami persamaan dan perbedaan budaya antara dirinya dan petutur dan dapat menghargai baik identitas dan budayanya sendiri maupun identitas dan budaya petutur.

Komponen kompetensi lintas budaya yang selanjutnya adalah 'sikap' (attitudes). Sikap yang diharapakan dikuasai oleh seorang penutur komunikasi lintas budaya adalah rasa ingin tahu (curiosity) dan keterbukaan (openness) terhadap budaya lain termasuk terhadap nilai identitas diri, keyakinan (beliefs) dan perbuatan-perbuatan yang barangkali berbeda dengan yang dimiliki si penutur sendiri.

Terakhir, komponen kompetensi lintas budaya yang harus dikuasai seorang penutur komunikasi lintas budaya adalah "nilai identitas diri' (individual value). Nilai identitas diri yang dimaksud adalah kesadaran terhadap budaya dan negara sendiri secara kritis, kemudian terhadap budaya dan negara petutur yang berbeda.

Pengembangan Bahan Ajar Bahasa Asing dalam Konteks Komunikasi Lintas Budaya

Anthony J. Liddicoat (2013: 63) mengungkapkan bahwa untuk membangun kompetensi komunikasi lintas budaya dalam diri pemelajar bahasa perlu dirancang penugasan dalam alur pembelajaran yang membangun proses kesadaran identitas diri dan saling memahami identitas orang lain di antara sesama pemelajar. Untuk itu, lebih lanjut 
Liddicoat menjelaskan bahwa penugasan di dalam kelas harus difokuskan pada 'interaksi" dan 'pengalaman'. Artinya sedapat mungkin kegiatan yang diciptakan memungkinkan pemelajar saling berinteraksi satu sama lain dan saling memberikan pengalaman dalam proses penemuan identitas diri dan mitra komunikasi. Pada akhirnya dihadapkan adanya penghargaan satu sama lain akan identitas diri yang berbeda karena perbedaan geografis. Untuk menciptakan 'interaksi' dan 'pengalaman' tersebut Liddicoat menyarankan untuk memanfaat perkembangan teknologi untuk meniadakan permasalahan keterbatasan 'ruang' dan 'waktu'. Perkembangan teknologi dapat digunakan sebagai media untuk meberikan 'interaksi' dan 'pengalaman' berkomunikasi lintas budaya seperti melalui e-mail, chat, blog, video, video komunikasi dan lain-lain. (Liddicoat \& Scarino, 2013: 119).

\section{METODE PENELITIAN DAN TEKNIK PENGUMPULAN DATA}

\section{Metode Penelitian, Sumber Data dan Responden Penelitian}

Metode penelitian yang akan dilakukan adalah penelitian tindakan kelas (Action Research). Adapun respondennya adalah peserta kuliah percakapan bahasa Jepang 2 (Kaiwa 2) di Universitas Al Azhar Indonesia sebanyak 21 orang.

Sumber data tema percakapan akan diambil dari buku ajar utama Minna no Nihongo (MNN) 1 dan buku ajar Marugoto. Buku ajar utama MNN 1 untuk pendekatan fungsi bahasa dan buku ajar Marugoto A0-A2 untuk pendekatan tema budaya.

Seperti yang terlihat pada Gambar 2, lima orang responden pernah belajar bahasa Jepang kurang dari dua tahun di sekolah menengah atas namun sebatas bahasa Jepang pengantar saja. Sedangkan enam belas responden lainnya pertama kali belajar bahasa Jepang setelah masuk UAI dan hingga penelitian dilakukan telah belajar bahasa Jepang kurang dari setahun.

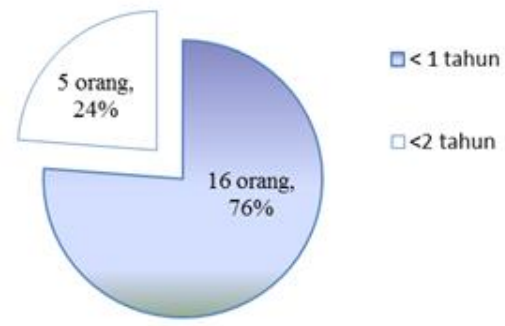

Gambar 2. Pengalaman Belajar Bahasa Jepang Responden

Dari dua puluh satu responden, hanya satu orang saja yang pernah mengikuti JLPT (Japanese Language Proficiency Test) dan lulus level N4 (kemampuan setara A2 CEFR dan JFS). Ilustrasi pengalaman mengikuti JLPT ini diperlihatkan pada grafik 3.2 di bawah ini.

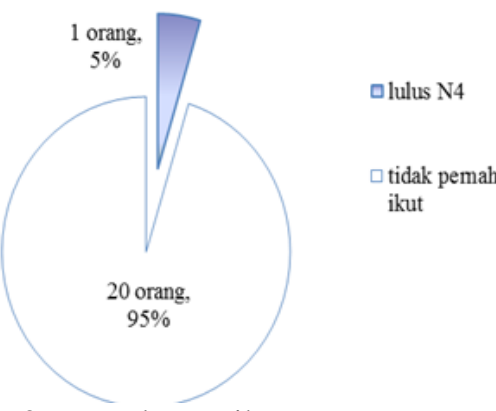

Gambar 3. Pengalaman ikut JLPT

\section{Metode Pengumpulan Data}

Penelitian tindakan kelas ini akan dilaksanakan dengan alur penelitian sebagai berikut.

1. Studi pustaka landasan teori dan penelitian terkini yang menjadi acuan

2. Mengkaji fungsi-fungsi bahasa yang muncul pada satuan acara pembelajaran (SAP) berdasarkan buku Minna no Nihonggo 1 sebanyak 7 tatap muka yang terdiri dari tujuh bab dalam buku ajar tersebut (Bab 14-21).

3. Kemudian data-data mengenai fungsi bahasa tersebut, disesuaikan dengan buku ajar lainnya yaitu "Marugoto A0-A2" yang merupakan buku ajar dengan pendekatan tematik budaya untuk mencari tema-tema percakapan apa yang dapat digunakan untuk berlatih meningkatkan kesadaran identitas diri saat berkomunikasi dalam bahasa Jepang.

4. Pada setiap awal tujuh tatap muka perkuliahan yang diamati dalam penelitian ini, pemelajar diminta untuk mengeksplorasi identitas dirinya sebagai 
muslim orang Indonesia, berkaitan dengan tema-tema yang telah dipilih melalui tahapan 1 dan 2. Eksplorasi ini dicatatkan dalam portfolio individu masing-masing responden.

5. Kemudian, pembelajar yang menjadi responden akan diberikan stimulan melalui gambar, video, bacaan dan lain-lain mengenai budaya orang Jepang berkaitan dengan tema-tema yang sudah dibicarakan di tahapan 3.

6. Responden diminta mendiskusikan dan memahami persamaan dan perbedaan identitas budaya orang Indonesia yang mayoritasnya muslim dengan identitas budaya orang Jepang serta kendala yang mungkin dihadapi akibat adanya perbedaan tersebut.

7. Dengan input identitas diri pada tahapan 3 dan input identitas orang Jepang pada tahapan 4, responden diminta untuk melakukan percakapan dengan bermain peran (role play). Kepada mereka diberikan situasi percakapan yang telah dikondisikan sesuai dengan tema pada tahapan 5. Sebagian responden akan tetap menjadi orang Indonesia dan sebagian yang lain akan berperan menjadi orang Jepang. Data ini akan direkam menjadi data video percakapan.

8. Selanjutnya mereka diminta mengevaluasi melalui rubrik dan port folio mengenai pengalaman berkomunikasi dalam bahasa Jepang dengan kesadaran identitas diri. Adapun faktor yang akan dievaluasi adalah perubahan cara pandang tentang kesadaran indentitas diri saat berkomunikasi dalam bahasa Jepang, kendala bahasa (pemilihan kosakata, tata bahasa, ungkapan serta tema percakapan apa yang dirasa sulit untuk menjelaskan identitas diri) dan kendala lain yang mungkin muncul.

9. Analisis data dilakukan dengan menganalisis hasil telaah fungsi bahasa dan tema pada buku ajar, rubrik dan port folio responden serta wawancara lanjutan jika dirasa perlu.

\section{HASIL DAN PEMBAHASAN}

Tema Percakapan Tingkat Dasar pada Kompetensi Komunikasi Interkultural

Tabel 1. Fungsi dan Tema Percakapan Komunikasi Interkultural Tingkat Dasar

\begin{tabular}{|c|c|c|}
\hline No & Fungsi Pola Kalimat & $\begin{array}{c}\text { Tema } \\
\text { Percakapan }\end{array}$ \\
\hline 1 & 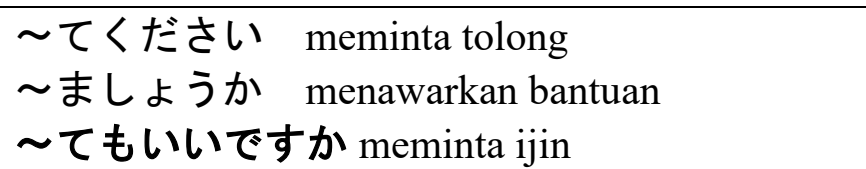 & Membantu \\
\hline 2 & $\begin{array}{l}\text { を知っていますかmenanyakan informasi } \\
\text { 〜が〜人います menjelaskan jumlah orang }\end{array}$ & Keluarga \\
\hline 3 & $\begin{array}{l}\text { 〜て、〜て〜ます menjelaskan urutan kegiatan } \\
\sim \tau / \text { 〜で } \quad \text { KSです ciri-ciri tempat }\end{array}$ & $\begin{array}{l}\text { Wisata di dalam } \\
\text { kota }\end{array}$ \\
\hline 4 & $\begin{array}{l}\text { 〜ないでください menjelaskan larangan } \\
\text { なければなりませんmenjelaskan keharusan } \\
\text { 〜なくてもいい menjelaskan ketidakharusan }\end{array}$ & $\begin{array}{l}\text { Wisata di dalam } \\
\text { kota }\end{array}$ \\
\hline 5 & $\begin{array}{l}\text { 〜ことができます } \\
\text { menjelaskan hal yang bisa dilakukan } \\
\sim こ と \text { menjelaskan kegemaran } \\
\sim \text { まえに、〜 } \\
\text { menjelaskan kegiatan sebelum kegiaatan lain }\end{array}$ & $\begin{array}{l}\text { Kegemaran dan } \\
\text { Kemampuan }\end{array}$ \\
\hline 6 & $\begin{array}{l}\text { 〜たことがあるmenjelaskan pengalaman } \\
\text { 〜たり〜するmenjelaskan beberapa kegiatan } \\
\text { tidak berurutan }\end{array}$ & Kesan perjalanan \\
\hline
\end{tabular}




\begin{tabular}{|c|l|l|}
\hline No & \multicolumn{1}{|c|}{ Fungsi Pola Kalimat } & \multicolumn{1}{|c|}{$\begin{array}{c}\text { Tema } \\
\text { Percakapan }\end{array}$} \\
\hline 7 & $\begin{array}{l}\text { 〜ななる } \\
\text { 〜を知っている } \\
\text { menanyakan infiormasi secara informal }\end{array}$ & $\begin{array}{l}\text { Pergi dengan } \\
\text { teman }\end{array}$ \\
\hline
\end{tabular}

Dari hasil pengumpulan data fungsi percakapan yang muncul pada buku ajar MNN1 pada tujuh tatap muka perkuliahan yang diteliti, kemudian ditelusuri tema-tema percakapan yang sesuai dengan buku ajar Marugoto A1 dan A2. Penyesuaian fungsi dan tema percakapan ini mengacu pada standar kemampuan bahasa Jepang tingkat A1 pada standar JFS 2010 dan CEFR.

Fungsi dan tema percakapan tersebut kemudian dibandingkan dengan standar kemampuan bahasa Jepang A1 JFS dan CEFR, kemudian dibuat target kompetensi percakapan untuk masing-masing tema. Target kompetensi percakapan tersebut diarahkan agar pembelajar menyadari identitas dirinya sebagai muslim orang Indonesia yang berkomunikasi dengan orang Jepang. Tabel $1 \mathrm{di}$ atas menunjukkan data fungsi, tema dan target kompetensi komunikasi interkultural percakapan yang dapat mengeksplorasi kesadaran identitas diri pembelajar pada konteks komunikasi interkultural.

Fungsi, Tema dan target yang diperlihatkan pada tabel 1 berkaitan dengan "identitas" dan "kegiatan sehari-hari". Hasil temuan ini sejalan dengan standar kemampuan berkomunikasi dalam bahasa asing pembelajar tingkat dasar tingkat A1 menurut JFS 2010 dan CEFR bahwa pembelajar tingkat dasar mampu menjelaskan identitas orang di sekitarnya dan kegiatan sehari-harinya dengan catatan menggunakan berbagai bantuan seperti gambar dan gerak tubuh dan dipersiapkan terlebih dahulu. Penggunaan bantuan dan persiapan tersebut mempertimbangkan lama belajar di tingkat dasar yang belum panjang dan penguasaan komponen lingustik (kosakata, ungkapan dan pola kalimat) yang diperolehpun masih terbatas.

\section{Kesadaran Identitas Diri Muslim Orang Indoensia dan Orang Jepang}

Hasil analisis portofolio, rubrik dan angket menunjukkan kesadaran identitas diri orang Indonesia termasuk identitas muslim yang dibandingkan dengan identitas diri orang Jepang yang berkaitan dengan tema-tema percakapan

Selain itu, kesadaran identitas diri yang mereka peroleh melalui proses pengambilan data juga menunjukkan bahwa mereka tidak hanya dapat menyadari pebedaan, namun juga dapat mengidentifikasi persamaan-persamaan di antara kedua identitas budaya lokal tersebut. Kemudian, responden juga dapat mengidentifikasi kendala-kendala linguistik yang mereka hadapi saat berkomunikasi dalam bahasa Jepang dengan tema-tema yang ditentukan.

Tabel 2. Identitas Diri Orang Indonesia dan Orang Jepang

\begin{tabular}{|c|c|c|c|}
\hline \multirow{2}{*}{ Topik } & \multicolumn{2}{|c|}{ Kesedaran Identitas } & \multirow{2}{*}{$\begin{array}{c}\text { Kendala } \\
\text { Lingusitik }\end{array}$} \\
\hline & Orang Indonesia & Orang Jepang & \\
\hline Keluarga & $\begin{array}{l}\text { Bercakap dengan topik } \\
\text { yang lebih luas dan } \\
\text { lebih } \\
\text { meskipun dengan orang } \\
\text { yang tidak akrab seperti } \\
\text { tempat tinggal, } \\
\text { pekerjaan, latar } \\
\text { belakang pendidikan, } \\
\text { asal, ciri-ciri fisik, } \\
\text { karakter umum, status } \\
\text { pernikahan } \\
\text { kegemaran, saudara }\end{array}$ & $\begin{array}{l}\text { Bercakap dengan topik } \\
\text { yang umum seperti } \\
\text { jumlah anggotan } \\
\text { keluarga dan hubungan, } \\
\text { arti nama, tempat lahir, } \\
\text { pekerjaan, saudara } \\
\text { kandung dan kegemaran }\end{array}$ & $\begin{array}{l}\text { Keterbatasan } \\
\text { kosakata dan } \\
\text { strategi } \\
\text { menjelaskan } \\
\text { tentang makna } \\
\text { nama, } \\
\text { pekerjaan dan } \\
\text { kegemaran } \\
\text { yang spesifik } \\
\text { hubungan } \\
\text { kekerabatan }\end{array}$ \\
\hline
\end{tabular}




\begin{tabular}{|c|c|c|c|}
\hline \multirow{2}{*}{ Topik } & \multicolumn{2}{|c|}{ Kesedaran Identitas } & \multirow{2}{*}{$\begin{array}{c}\text { Kendala } \\
\text { Lingusitik }\end{array}$} \\
\hline & Orang Indonesia & Orang Jepang & \\
\hline & $\begin{array}{l}\text { kandung dan kerabat } \\
\text { yag tinggal bersama }\end{array}$ & & \\
\hline $\begin{array}{l}\text { Wisata dalam } \\
\text { kota }\end{array}$ & $\begin{array}{l}\text { Bercakap tentang objek } \\
\text { wisata lokal, lokasi dan } \\
\text { keragaman } \\
\text { transportasi lokal,,hal } \\
\text { yang menarik, sejarah, } \\
\text { makanan lokal yang } \\
\text { bervariasi } \\
\text { pemandangan yang } \\
\text { menarik, waktu yang } \\
\text { baik untuk dikunjungi, } \\
\text { landmark sekitar } \\
\text { termasuk masjid atau } \\
\text { tempat ibadah lain }\end{array}$ & $\begin{array}{l}\text { Bercakap tentang objek } \\
\text { wisata lokal, hal yang } \\
\text { menarik, lokasi dan } \\
\text { transportasi lokal yang } \\
\text { relatif seragam } \\
\text { sejarah, makanan lokal } \\
\text { yang variasi produk } \\
\text { unggulan setempat , } \\
\text { pemandangan yang } \\
\text { menarik, waktu yang } \\
\text { baik untuk dikunjungi, } \\
\text { landmark sekitar }\end{array}$ & $\begin{array}{l}\text { Hambatan } \\
\text { gramatikal } \\
\text { untuk } \\
\text { menjelaskan } \\
\text { sejarah dan } \\
\text { keterbatasan } \\
\text { kosakata } \\
\text { mengenai } \\
\text { bahan pangan } \\
\text { dan cara } \\
\text { mengolah }\end{array}$ \\
\hline & 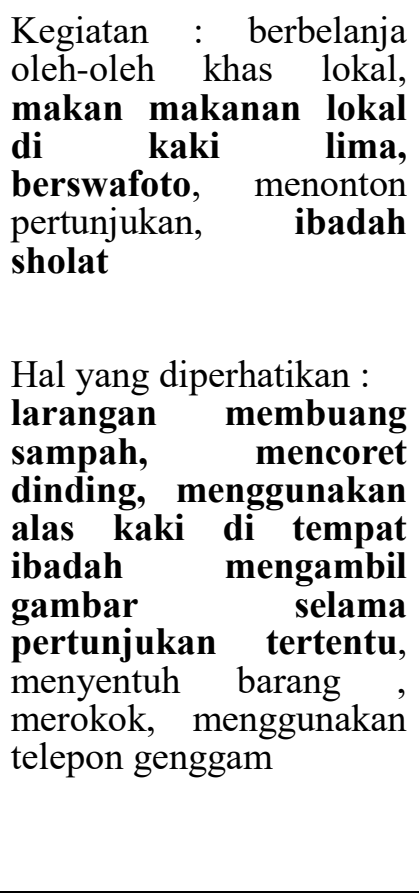 & $\begin{array}{l}\text { Hal yang harus } \\
\text { diperhatikan : larangan } \\
\text { berswafoto, larangan } \\
\text { keras mengambil } \\
\text { gambar, merokok di } \\
\text { area tertentu, } \\
\text { menggunakan telepon } \\
\text { genggam, membawa } \\
\text { makanan minuman } \\
\text { dari luar, makan dan } \\
\text { minum dalam ruangan, } \\
\text { menyentuh display }\end{array}$ & $\begin{array}{l}\text { Keterbatasan } \\
\text { kosakata untuk } \\
\text { menjelaskan } \\
\text { transportasi } \\
\text { local dan bahan } \\
\text { suvenir } \\
\text { Kesulitan } \\
\text { secara } \\
\text { garamatikal dan } \\
\text { kosakata untuk } \\
\text { menjelaskan } \\
\text { alasan larangan }\end{array}$ \\
\hline
\end{tabular}

Dari hasil analisis data terlihat bahwa tema percakapan yang menunjukkan banyaknya kesadaran identitas diri yang teridentifikasi sebagai pembeda identitas orang Indonesia dan orang Jepang adalah tema "Keluarga" dan tema "Wisata dalam kota". Hasil identifikasi ini ditampilkan pada Tabel 2. Pada tabel terlihat bahwa orang Indoenesia ketika membicarakan tentang anggota keluarganya sekalipun dengan orang yang tidak akrab, akan dapat mengembangkan tema ke dalam sub-sub tema yang lebih mendalam seperti arti nama, asal, status pernikahan, latar belakang pendidikan. Berbeda dengan orang Jepang yang hanya menjelaskan sub-sub tema yang sifatnya umum seperti jumlah anggota keluarga, pekerjaan dan kegemaran.

Berkaitan dengan percakapan identitas asal, pada data teridentifikasi bahwa ada perbedaan konsep pada orang Indonesia dan orang Jepang. Identitas asal bagi orang Indonesia adalah asal orangtua yang sifatnya turun temurun. Sementara bagi orang Jepang, identitas asal lebih berarti "tempat dilahirkan dan dibesarkan". Perbedaan konsep "identitas asal" ini ada kecenderungan memunculkan kebingungan pada orang Jepang mitra komunikasi mereka ketika orang Indonesia menjelaskan identits asal kedua orang tuanya yang berbeda. 
Kemudian, pada beberapa sub tema percakapan terlihat bahwa keterbatasan penguasaan gramatika dan kosa kata pada orang Indonesia pembelajar bahasa Jepang tingkat dasar, menyebabkan mereka kesulitan untuk menjelaskan identitas lokal yang sifatnya khusus seperti pekerjaan non formal, hubungan kekerabatan (pada orang Indonesia, identitas keluarga adalah seluruh keluarga dan kerabat; sedangkan pada orang Jepang yang disebut keluarga adalah keluarga inti saja), bahan pangan makanan lokal dan cara memasaknya, jenis-jenis transportasi lokal, bahan dasar souvenir dan cara membuatnya, serta alasan larangan di suatu tempat wisata. Pada beberapa responden terindentifikasi usaha untuk menyiasati kendala tersebut seperti dengan menggunakan kosakata bahasa Inggris, bantuan ilustrasi gambar dan bahasa tubuh.

Pada tema percakapan "Wisata dalam Kota" banyak persamaan identitas diri antara orang Jepang dan orang Indonesia. Namun, teridentifikasi perbedaan-perbedaan kondisi setempat yang membuat pembelajaran kesulitan menjelaskan perbedaan tersebut. Misalnya terdapat perbedaan kebiasaan melakukan aktivitas bersama di tempat publik seperti berswafoto yang sedang digemari orang Indonesia. Ketika melakukan percakapan ini, sebagian besar responden kesulitan untuk menjelaskan alasan suatu larangan di tempat publik termasuk tempat wisata.

Kemudian, teridentifikasi bahwa salah satu kegiatan penting yang dilakukan oleh responden sekalipun saat berwisata adalah ibadah sholat. Kegiatan ini terkait dengan identitas dirinya sebagai seorang muslim. Oleh karena itu banyak responden yang berusaha menjelaskan aturan atau hal-hal yang harus diperhatikan ketika memasuki tempat sholat, termasuk kebiasaan melepas sepatu atau alas kaki lainnya. Pada bagian ini beberapa responden mengungkapkan kesulitan untuk menjelaskan alasan dari larangan tersebut.

\section{KESIMPULAN DAN SARAN}

\section{Kesimpulan}

Hasil penelitian ini menunjukkan bahwa melalui penelitian tindakan ini, responden orang Indonesia pembelajar bahasa Jepang tingkat dasar menyadari identitas dirinya termasuk identitas diri sebagai muslim orang Indonesia saat melakukan percakapan komunikasi intercultural.

Kesadaran sebagai orang Indonesia adalah kesadaran bahwa orang Indonesia cenderung terbuka untuk berbagai topik pembicaraan termasuk pembicaraan dengan orang yang tidak dikenal dan memungkinan untuk terlibat percakapan dalam topik-topik yang bersifat personal seperti keluarga.

Sebagai salah satu alasan yang dianggap memungkinkan orang Indoesia seperti demikian adalah konsep "Keberagaman dalam satu kesatuan" (Bhinneka Tunggal Ika). Dengan keberagaman ini orang Indonesia cenderung adaptif dengan berbagai mitra komunikasi dan berbagai topik. Namun keterbatasan penguasaan komponen lingusitik (kosakata, gramatika dan lain-lain) membuat mereka mengalami hambatan linguistik yang membutuhkan strategi untuk mengatasi hambatan pada komunikasi interkultural tersebut.

Sementara orang Jepang, dengan identitas budaya berkelompok (collectivistic culture) cenderung menjaga privasi ketika membicarakan topik-topik yang dianggap personal terutama di hadapan mitra komunikasi yang tidak akrab. Pada situasi demikian mereka cenderung hanya membicarakan hal-hal yang bersifat umum.

Adapun tema percakapan di pembelajaran tingkat dasar yang memungkinkan untuk banyak mengeksplorasi kesadaran identitas diri adalah tema "Keluarga" dan " Wisata dalam Kota“.

\section{Kelemahan dan Saran}

Ada beberapa hal yang disadari sebagai kelemahan penelitian ini. Pertama, jumlah responden penelitian ini relatif sedikit sehingga data penelitian tidak bisa diolah secara statistik. Untuk penelitian lanjutan, ada baiknya jumlah responden ditambah dengan melakukan penelitian bersama dengan dosen di kampus lain sehingga dapat memenuhi jumlah responden yang ideal untuk data penelitian.

Kelemahan yang kedua yaitu, mitra percakapan dalam penelitian tindakan ini adalah orang Indonesia sesama pembelajar bahasa Jepang. 
Dengan demikian, perbedaan identitas budaya yang mereka sadari tidak mereka peroleh secara langsung, melainkan dengan bantuan video, gambar dan lain-lain. Untuk penelitan lanjutan sebaiknya dikondisikan agar mitra percakapan adalah orang Jepang.

\section{DAFTAR PUSTAKA}

[1] S. Hall, "Cultural identity and diaspora," in Diaspora and visual culture, Routledge, 2014, hal. 35-47.

[2] F. E. Jandt, Intercultural communication: A global reader. Sage, 2004.

[3] F. E. Jandt, An introduction to intercultural communication: Identities in a global community. Sage Publications, 2017.

[4] M. Byram, B. Gribkova, dan H. Starkey, "Developing the intercultural dimension in language teaching," A Pract. Introd. Teach. Strasbg. Counc. Eur., 2002.

[5] M. Byram, A. Nichols, dan D. Stevens, Developing intercultural competence in practice, vol. 1. Multilingual Matters, 2001.

[6] M. Byram, P. Holmes, dan N. Savvides, "Intercultural communicative competence in foreign language education: Questions of theory, practice and research," Lang. Learn. J., vol. 41, no. 3, hal. 251-253, 2013. 